ks. Edward Sienkiewicz

Uniwersytet Szczeciński

DOI: 10.15290/std.2020.06.11

0000-0002-6711-9933

\title{
TEOLOGIA JAKO WIEDZA PRAKTYCZNA
}

\section{THEOLOGY AS PRACTICAL KNOWLEDGE}

Regardless of the solutions to the problem posed in this way, at least one is beyond discussion: in the practical dimension of systematic reflection of faith, it is about knowledge. Besides, it is theology that is the most appropriate way to defend knowledge against one-sided and partial approaches. It is determined by two issues that constitute an interpretative key in solving the problem posed: sense and context, as well as - in this perspective - two dimensions: cognition and free will. Therefore, in order to define the nature and importance of theology as practical knowledge, the problem of utilitarianism in science as such must first be solved. The turning point here is the Marxist appreciation of revolutionary praxis, which gives philosophy a new and practical meaning. It posed a particular challenge to theology and the objective nature of truth as a fundamental question in science. Both the Bible and the Christian systematic reflection of faith developed over the centuries clearly show that faith in Almighty God has a practical character. This means that faith cannot be reduced to knowledge only, just as faith cannot give up the problem of truth. In this sense, theology as practical knowledge, that is, on the basis of faith, a specific spiritual attitude and the choices that flow from it, is a proper understanding of the necessary participation of human reason, revelation and life in this event. From a Christological perspective, the best definition of theology as practical knowledge are the words from John's Gospel: "I am the way, the truth and the life" (Jn 14: 6). In such an approach, the practical dimension of reflection on faith is simply love - first as the perfect fulfillment of the Law (Rom 13:10), and then as caritas, that is, a gift that does not retreat from renunciation and suffering. This means the necessity in this problem of the revealed truth about the Holy Trinity, in which the relationships of giving and accepting in love are 
difficult to consider theoretically. Just as practical and theoretical knowledge should not be opposed, knowledge and wisdom should not be confronted or separated. For theology, as wisdom, not only knows, but also knows why it knows and what to do with what it knows; not only poses the question of how to live, but also answers them. In other words, the practical dimension of systematic reflection of faith is essential for theology to be not only debatable, but also kneeling and working.

Key words: theology, knowledge, science, practice, faith, truth, love, wisdom, cognition, free will, philosophy.

Na początku wypada rozwiać ewentualne wątpliwości co do charakteru wiedzy, określanej jako „praktyczna”. Co ciekawe, autorzy Encyklopedii katolickiej nie widzą takiego problemu ${ }^{1}$. I nie wygląda to tak samo w innych leksykonach, słownikach i encyklopediach, w tytułach których dookreślenia chrześcijańskiego czy też katolickiego, próżno szukać ${ }^{2}$ W wiedzy praktycznej, która - zgodnie z najbardziej rozpowszechnionymi definicjami - jest rezultatem poznania, chodzi o prawdę 3 . Inaczej mówiąc - jeśli już wspominamy o nawiązaniu i uwzględnieniu innych rezultatów poznania, np. „wiedzę teoretyczną" - chodzi o pełen obraz prawdy, do którego wiedza praktyczna nie tylko się przyczynia, ale jest niezbędna. Jezus bowiem nie mówi: „Ja najlepiej prawdy nauczam; objawiam; ukazuję najbardziej skuteczny sposób docierania do niej”, ale mówi: „Ja jestem prawdą...” (J 14, 6), co wykracza zdecydowanie poza wymiar teoretyczny. Zastrzeżenie to wydaje się potrzebne także ze względu na wyraźne przeciwstawianie sobie wiedzy praktycznej i teoretycznej lub jeszcze częstsze jednostronne ujmowanie tego fenomenu. I wreszcie, tak bardzo ogólne sformułowanie tematu, pozwala jedynie na ukazanie pewnych zasad, które oczywiście można i należy rozwinąć, co jednak nie jest możliwe w jednym, nawet obszernym artykule.

1 Autor hasła: Wiedza drobiazgowo wylicza jej „odmiany” i „typy”, nie dostrzegając jednak, dość powszechnego w innych opracowaniach, podziału wiedzy na teoretycznąi i praktyczną. P. Kawalec, Wiedza, [w:] Encyklopedia katolicka, t. XX, (red. nacz.) E. Gigilewicz, Lublin 2014, kol. 485-487.

2 Wielka ilustrowana encyklopedia powszechna, t. XVIII, Kraków 1932, s. 106; Wielka encyklopedia powszechna PWN, t. 12, Warszawa 1969, s. 251-252; Nowa encyklopedia powszechna PWN, t. 6, (red.) B. Petrozolin-Skowrońska, Warszawa 1996, s. 733; Encyklopedia popularna PWN, (red.) J. Kofman, Warszawa 1992, s. 931.

3 J. Ratzinger, Rozumienie objawienia $i$ teologia historii wedtug Bonawentury. Rozprawa habilitacyjna i studia nad Bonawentura, „Opera Omnia”, t. II, tłum. J. Merecki, (red.) K. Góźdź, M. Górecka, Lublin 2014, s. 335-337. 


\section{Scientia fidei - nauka czy życie?}

W celu wprowadzenia w ten dylemat - nie rozstrzygając na razie o jego faktyczności czy tylko sztucznej konstrukcji myślowej (posiadającej oczywiście swoje przyczyny i skutki) - zostaną przywołane dwa obrazy, które zdają się przybliżać nieco istotę postawionego problemu lub przynajmniej zarysowują właściwe temuż przedpola.

W drugiej połowie lat 80. XX wieku, na KUL-u zorganizowano kilkudniowe sympozjum na temat deterministycznego lub indeterministycznego charakteru naszej rzeczywistości. Ukazując chrześcijańską propozycję rozwiązania tego problemu o. prof. Mieczysław Albert Krąpiec przywołał anegdotę, przypisywaną o. Woronieckiemu, przyblizającą mechanizm autodeterminizmu podmiotu, jako wypadkową „współpracy” rozumu i woli. Opowiada ona o atletycznym, bardzo sprawnym fizycznie siłaczu, ale niewidomym oraz bardzo dobrze widzącym, jednak bez możliwości poruszania się, karle. W pojedynkę obaj bez jakiejkolwiek gwarancji przeżycia. Postanawiają zatem żyć w symbiozie. Bierze więc ów siłacz karła na swoje potężne barki i każe mówić, co widzi, aby wiedział, którędy ma iść i co robić. - Widzę kwiatki - powiada ten drugi - las, pole drogę i wielkie błoto. Wtem ów siłacz zanurza się w tym ostatnim, argumentując to - wiele i dla wielu znaczącym oraz traktowanym jako wystarczające usprawiedliwienie oraz wytłumaczenie - „przecież to bardzo lubię”.

Drugi obraz jest znacznie bliższy w czasie. Na pogrzebie ks. prof. Czesława Bartnika ks. prof. Krzysztof Góźdź wygłosił poruszającą homilię. Warto ją zapamiętać, ponieważ w wyjątkowy sposób oddaje fenomen wielkiego lubelskiego teologa. Wspomniał w niej o pytaniu, które zadał kiedyś swojemu mistrzowi: „Czy Profesor nie boi się śmierci?” Czy „przypadkiem” pytanie to, a zwłaszcza udzielona na nie odpowiedź, nie wprowadza wprost w zagadnienie teologii jako wiedzy praktycznej właśnie. A może zakreśla tylko oczywiste granice, nie bagatelizując po drodze wszystkich związanych z tym trudności, ale i zdobyczy. Otóż ks. prof. Bartnik miał odpowiedzieć - jak twierdził ks. Góźdź - że „pragnie w wieczności spotkać się z kapłanami staroegipskimi, głoszącymi przebóstwienie ludzkiej duszy". Czy w tych granicach i w tym wymiarze, mieści się również postulat - zgłaszany m.in. przez Josepha Ratzingera - o uczynienie z eschatologii centrum chrześcijańskiej refleksji wiary? Pamiętając jednocześnie, że nadal, z punktu widzenia niektórych, wielkich systemów teologicznych i ważnych teologów, eschatologia wciąż pozostaje zamknięta w wysoce teoretycznych rozważaniach ${ }^{4}$.

$4 \quad$ A. Nossol, Teologia bliższa życiu. Wplyw teologii na egzystencję chrzésijańska, Paris 1993, s. $267-300$. 
Obrazy te - jak się wydaje - ukierunkowują refleksję na temat praktycznego znaczenia teologii, w bardzo charakterystycznych wymiarach: ludzkiej woli, podejmującej działanie na podstawie poznania (rozumu); weryfikacji intelektualnego poszukiwania zrozumienia wiary ${ }^{5}$ (co może być większym wyzwaniem wobec sensu, niż śmierć? $\left.{ }^{6}\right)$ i wreszcie właściwego „miejsca” kształtowania się chrześcijańskiego Credo ${ }^{7}$. Zanim rozpatrzymy te trzy wymiary, wydaje się potrzebne zwrócenie uwagi na pewien moment przełomowy, po którym nauki już nie rozumiano w taki sam sposób, z czym związane jest również inne, niż przed owym przełomem, kierowane wobec niej oczekiwanie. Inny problem, którego ze względu na sformułowany temat nie można w tym miejscu pominąć, to kwestia każdorazowego kontekstu teologii. Należy go rozumieć jako w ogóle możliwość - jak to ujął Stanisław Bobrowski - „ocalania przez teologię ludzi i narodów"8. I choć w praktycznym wymiarze teologii ma on bezsprzecznie wielkie znaczenie, raczej nie zachodzi w tym miejscu potrzeba rozwijania tego zagadnienia, ponieważ w literaturze, zwłaszcza w ostatnim czasie, jest ono szeroko i wnikliwie opracowywane? .

5 B. Ferdek, Światlo wiary w obliczu światła rozumu, [w:] Problem kulturowo-religijnej reinterpretacji wspótczesnej Europy, (red.) J. Moskałyk, Poznań 2019, s. 139.

6 J. Ratzinger, Zmartwychwstanie $i$ życie wieczne. Studia o eschatologii i teologii nadziei, tłum. J. Kobienia, „Opera Omnia”, t. X, tłum. J. Kobienia, (red.) K. Góźdź, M. Górecka, Lublin 2014, s. 287-289.

7 Jak powie Joseph Ratzinger: „W wierze chodzi o sztukę życia. Wiara ma na celu umiejętność życia. Nie chodzi w niej o taką czy inną umiejętność, którą można nabyć, ale też zaniechać; chodzi w niej o nauczenie się samego życia i to takiego życia, jakie jest godne i zdolne do tego, by trwać wiecznie". J. Ratzinger, Wiara w Piśmie i Tradycji. Teologiczna nauka o zasadach, tłum. J. Merecki, „Opera Omnia”, t. IX / 2, (red.) K. Góźdź, M. Górecka, Lublin 2018, s. 829.

$8 \quad$ J. Szymik, O teologii dzisiaj. Zadania, piękno, przysztość, Pelplin 2006, s. 91.

9 B. Häring, Siła istabość religii. Socjologia religii jako wyzwanie, tłum. J. Klenowski, Poznań 1966; K. Rahner, Podstawowy wyktad wiary. Wprowadzenie do pojęcia chrześcijaństwa, tłum. T. Mieszkowski, Warszawa 1987, s. 325-332; H. Waldenfels, O Bogu, Jezusie Chrystusie i Kościele - dzisiaj. Teologia fundamentalna w kontekście czasów obecnych, tłum. A. Paciorek, Katowice 1993; H. U. von Balthasar, Teodramatyka, 1 Prolegomena, tłum. M. Mijalska, M. Rodkiewicz, W. Szymona, Kraków 2005, s. 13-80; 119-240; G. L. Müller, Raport o stanienadziei. Rozmowa z Carlosem Granadosem, tłum. K. Jasiński, Warszawa 2018; J. Szymik, O teologii dzisiaj, s. 45-46; R. Kuligowski, Jak żyć wiara?, [w:] Perspektywy wiary, (red.) M. Jagodziński, Radom 2015, s. 128; J. Wojtkun, Lumen fidei $i$ Veritatis splendor - światło wiary w blasku prawdy moralnej, [w:] Perspektywy wiary, s. $144-148$. 


\section{W odkrywaniu praktycznego znaczenia wiedzy moment zwrotny}

Rzetelnie trzeba przyznać, że próby praktycznej weryfikacji ludzkiej wiedzy, mają długą i złożoną historię. Niemniej jedno wydarzenie wydaje się być w tym procesie bardzo ważne, wręcz epokowe. Zwrócił na nie uwagę m.in. Wojciech Roszkowski w swojej książce pt. Roztrzaskane lustro. Upadek cywilizacji $z_{a c h o d n i e j}{ }^{10}$. To oczywiście nie jedyny w literaturze wyraz świadomości niebezpiecznego zjawiska w rzeczonym procesie. Niemniej wspomniany autor czyni to w sposób - w związku z rozwiązywanym tu problemem - nad wyraz trafny. Cywilizację bowiem, która m.in. przez to wydarzenie jest zagrożona, a właściwie według Roszkowskiego upada, trzeba nazwać chrześcijańską, czyli ukształtowaną na podstawie wiary i systematycznej refleksji nad nią, co ma swoje, bardzo daleko idące, konsekwencje praktyczne.

O jakie wydarzenie chodzi? O marksistowskie dowartościowanie rewolucyjnej praxis, która miała być korektą każdej scientia i zarazem „skokiem do królestwa wolności" ${ }^{11}$. Co to oznacza? Karol Marks - mimo szeregu wielkich błędów, które poważnie zaważyły na dalszym poszukiwaniu i określaniu pierwszych przyczyn wszechrzeczy - przyczynił się do wielkiego przełomu. Jako pierwszy zrobił praktyczny użytek z filozofii, która w swoich dotychczasowych dziejach $-z$ wyłączeniem bodajże pierwszych starogreckich mędrców, rozumiejących ją jako najlepszą drogę do osiągnięcia szczęśliwej egzystencji miała charakter od praktyki bardzo odległy, czyli na wskroś teoretyczny. Marks stwierdził: „Filozofowie dotychczas tylko rozmaicie interpretowali świat; chodzi zaś o to, by go zmieniać” ${ }^{12}$. Przy czym przywołania filozofii w tym tekście nie należy traktować jako przypadkowego, gdyż jej znaczenia w refleksji wiary usprawiedliwiać i dowodzić raczej nie trzeba.

Czy zatem powszechny dziś utylitaryzm wiedzy i nauki (dominujący zwłaszcza w postpozytywistycznym obrazie nauk szczegółowych) ma charakter marksistowski? Nie. Podobnie jak marksizm nie jest ostatnim kamyczkiem do tego ogródka i nie pierwszym, choć bez wątpienia bardzo ważnym na drodze długiego procesu. Proces ów wolno, jak się wydaje, rozumieć jako uprzyczynowany w większym lub mniejszym stopniu - ciąg zdarzeń. Oczywiście w stałym odniesieniu do rozpatrywanego problemu teologii jako wiedzy praktycznej. Jakie zatem wydarzenia składają się na praktyczną - utylitarną dominację ludzkiej

10 W. Roszkowski, Roztrzaskane lustro. Upadek cywilizacji zachodniej, Kraków 2019, s. 83-85.

$11 \quad$ A. Walicki, Marksizm i skok do królestwa wolności. Dzieje komunistycznej utopii, Warszawa 1996.

12 K. Marks, Tezy o Feuerbachu, [w:] tenże, Dzieła, t. III, Warszawa 1961, s. 25. 
wiedzy, co nie może pozostać obojętne dla teologii? ${ }^{13}$ Jak się okazuje należy sięgać bardzo daleko, aż do starogreckiego - nader praktycznego - traktowania umiłowania mądrości (filosofia) w celu osiągnięcia szczęśliwego życia; odkrycia przez tych samych Greków prawa naturalnego ${ }^{14}$ i związanego $z$ tym wyodrębnienia nomos obok logos i physis ${ }^{15}$. Dalej - nie bez wpływu wspomnianych, ale i innych, późniejszych osiągnięć - przeniesienie w epoce nowożytnej dotychczasowego zainteresowania Bogiem, traktowanego jako najważniejszy czynnik rozwoju nauki i ludzkiej wiedzy, na niezmienne i nieugięte prawa natury ${ }^{16}$. Poza tym zainteresowania w nauce nowożytnej faktami i w coraz mniejszym stopniu związkami między nimi oraz zastąpienie, jak się okazało wiele zmieniające, pojęcia prawa naturalnego, prawami natury - w liczbie mnogiej, co prowadziło do rozumienia ich jako praw ruchu ${ }^{17}$. Ograniczenie wreszcie nauki do tego, co doświadczalnie - empirycznie sprawdzalne i praktycznie potwierdzone ${ }^{18}$.

Oczywiście lista ta jest dyskusyjna i można podać jeszcze inne momenty oraz wydarzenia. Nie wszystkie je trzeba oceniać jako jednoznacznie negatywne dla samej nauki. Niemniej na każdym etapie stanowiły one poważne wyzwanie wobec teologii, aż do dziś, kiedy wiodące i uprzywilejowane kierunki w nauce

13 P. Kiejkowski, Trzy stowa papieża Benedykta XVI dla Europy. W trosce o integralny humanizm, [w:] Problem kulturowo-religijnej reinterpretacji wspótczesnej Europy, s. 94.

14 R. Brague, Prawo Boga. Filozoficzna historia przymierza, tłum. M. Wodzyńska, A. Kocot, Warszawa 2014, s. 43-44. 48-69.

15 J.-P. Vernant, Źródła myśli greckiej, tłum. J. Szacki, Gdańsk 1996, s. 2. 4. 47. 63. 84. 102; Pseudo-Platon, Zimorodek i inne dialogi, tłum. L. Regner, Warszawa 1985, 317 d. 321 bc; Ksenofont z Efezu, Pisma sokratyczne, tłum. L. Joachimowicz, Warszawa 1967, I, 2, 42.

16 I. Bokwa, Teologia w warunkach nowoczesności i ponowoczesności, Sandomierz 2010, s. $56-57$.

$17 \quad$ F. Oakley, Christian Theology and the Newtonian Science. The Rise of the Concept of the Laws of Nature, „Church History” 30 (1961), s. 433-457; L. Brunschvicg, Rozwój świadomości w filozofii zachodniej (fragmenty), tłum. T. Śliwiński, Kraków 2005; D. Hume, Eseje z dziedziny moralności, polityki i literatury, tłum. Ł. Pawłowski, Warszawa 2013; H. Bergson, Dwa źródła moralności i religii, tłum. P. Kostyło, Kraków 1993.

18 M. Heller, Nowa fizyka i nowa teologia, Tarnów 1992, s. 27; tenże, Wszechświat $i$ Stowo, Kraków 1994, s. 27; tenże, Nowa fizyka i nowa teologia, Tarnów 1992; M. Heller, Z. Liana, J. Mączka, W. Skoczny, Nauki przyrodnicze a teologia: konflikt i wspótistnienie, Tarnów 2001; M. Heller, J. Życiński, Drogi myślących, Kraków 1983, s. 5; L. Scheffczyk, Die Theologie und die Wissenschaften, Aschaffenburg 1989, s. 120; S. Hawking, A brief History of Time, Bantam Press 1988, s. 175; E. H. Hutten, Idee fizyki, Warszawa 1976, s. 174-175; M. Lubański, Filozoficzne zagadnienia teorii informacji, Warszawa 1976; N. Frye, The Great Code, Routledge and Kegan Paul 1982, s. 7; P. Ricoeur, The Rule of Metaphor, Routlege and Kegan Paul 1978, s. 288; P. Davies, Ostatnie trzy minuty. O ostatecznym losie wszechświata, Warszawa 1995; National Academy of Sciences, Teaching About Evolution and the Nature of Science, Washington 1998; J. Barrow, Theories of Everything: The Qwest for Ultimate Explanations, Oxford University Press 1991, s. 210. 
wyznacza możliwość jak najszybszego, praktycznego wykorzystania ich wyników, dzięki czemu żyć ma się nam bezpieczniej i wygodniej. Czy w takiej sytuacji marginalizacja teologii może jeszcze kogoś dziwić? I jakie znaczenie w utylitarystycznym dogmacie współczesnej - choć nie tylko - nauki ma to, że chodzi w niej przede wszystkim o prawdę, co teologowie wciąż jeszcze przypominają najczęściej i najgłośniej ze wszystkich uczonych? Pozbycie się złudzeń nie może jednak oznaczać wycofania się teologii ze sporu o prawdę i tym samym o kształt nauki oraz zgody na marginalizację.

\section{Historia problemu}

Jako pierwszego teologa w sensie praktycznym, w historii teologii, wymienia się Antonina Pierozziego (1389-1459). W swoim dziele Summa theologica lub Summa moralis, bazując na rozstrzygnięciach tomistycznych, zajmuje się on kwestiami ekonomicznymi, dążąc do uporządkowania praktycznych rozwiązań na podstawie Bożego prawa ${ }^{19}$. W ten nurt wpisuje się także twórczość teologów hiszpańskiego pochodzenia: Rodrigo Sáncheza de Arévalo (1405-1470) i Juana Torquemady $(1388-1468)^{20}$. Historycy jednak, na podstawie właściwej im metodologii, kierują się własnymi wyborami. Niekoniecznie zbieżnymi z wnioskami teologa systematycznego, zastanawiającego się nad praktyczną wartością refleksji wiary. W kwestii tej - jak się wydaje - ważnym odniesieniem w ocenie teologii, powinien być wspomniany kontekst. Czy w takiej perspektywie opinie - całkiem nieodosobnione - jakoby apologeci, zajmujący się w ich czasie kwestiami najbardziej aktualnymi, nie w pełni ukazywali depozyt wiary, koncentrując się na tym, co zagrożone ${ }^{21}$, powinniśmy uznać za wystarczający argument, przemawiający za pominięciem tego okresu w rozważaniach na

19 T. M. Izbicki, Protector of the Faith. Cardinal Johannes de Turrecremata and the Defense of Institutional Church, Washington 1981, s. 269. 293-294; Historia teologii, t. III, Epoka Odrodzenia, tłum. W. Szymona, (red.) G. D’Onofrio, Kraków 2008, s. 96-99.

20 Pierwszy koncentruje się na etycznym przygotowaniu władców do rządzenia państwem i rozstrzygania sporów, ale także pewnej weryfikacji wartości chrześcijaństwa w praktycznych rozwiązaniach wszystkich stanów i wykonywanych funkcji społecznych, gdzie wzorem i przykładem powinni być zakonnicy i duchowni. Z kolei Juan Torquemada widział Kościół jako doskonałe społeczeństwo, nie tylko w kontekście dążenia do wiecznej szczęśliwości; Zbawienia, ale również w rozwiązywaniu problemów tego świata - w praktycznych urzeczywistnieniach, co bez jakichkolwiek wątpliwości traktował jako przewyższające pod każdym względem jakiekolwiek pozachrześcijańskie uregulowania prawne i zasady obyczajowe. R. H. Trame, Rodrigo Sáncheza de Arévalo. Spanish dyplomat and champion of Papacy, Washington 1958; Historia Teologii, t. III, s. 131-135.

21 J. H. Newman, O rozwoju doktryny chrześcijańskiej, tłum. J. Zielińska, Warszawa 2000, s. 328-330; H. U. von Balthasar, Teodramatyka, 2 Osoba dramatu, cz. I, Człowiek w Bogu, tłum. W. Szymona, Kraków 2006, s. 126-141. 
temat jej praktycznego wymiaru? Wreszcie Biblia, od czego należałoby zacząć, zgodnie $z$ chronologicznym kluczem, w swoim kanonicznym układzie, na pierwszych stronach ukazuje Boga objawiającego się człowiekowi przez swoje fecit ${ }^{22}$. Natomiast w Nowym Testamencie, ogłaszający bliskie królestwo Boże Jezus, przypomina wędrownych, starogreckich mędrców, bardzo praktycznie podchodzących do ludzkiego szczęścia, ale ukazuje o wiele lepszą od nich i bardziej skuteczną do tego drogę. Jak powie Joseph Ratzinger: „Lektura Biblii $\mathrm{w}$ istocie nie pozostawia wątpliwości co do praktycznego charakteru wiary w Boga Wszechmogącego"23. Niezwykle pouczające i na pewno tylko potwierdzające praktyczną wartość ogłoszonej przez Jezusa Dobrej Nowiny, byłoby szczegółowe zagłębienie się w tekst Pisma Świętego ${ }^{24}$, co jednak rozsadziłoby zupełnie strukturę tego artykułu. Nie wolno jednak tego źródła i zawartej już w nim głębokiej teologii, w kwestii praktycznej wartości refleksji wiary, pomijać.

Podobnie jak rezygnować z pewnej - pouczającej z punktu widzenia tematów teologicznych, wpływających na chronologiczne rozstrzygnięcia - retrospekcji. I tak już Justyn, dowodząc uczoności i rozumności chrześcijan, nie ograniczał się do logos, ale za równie istotne uznawał w tym także orthos i nomos ${ }^{25}$. Z kolei Klemens Aleksandryjski w Kobiercach $(1,38)$, wiedzę uzależniał od woli Bożej, którą - jak to wyraził - „poznajemy, gdy ją pełnimy”" ${ }^{26}$. We wczesnym średniowieczu Anzelm, w swoim słynnym dowodzie, w poznaniu prawdy uwypukla doświadczenie ${ }^{27}, z$ wyraźną konotacją praktyczną ${ }^{28}$. Dla Bonawentury Najwyższa Prawda to wprawdzie scientia et sapientia, ale szczęście uważa za możliwe do osiągnięcia tylko dzięki syntezie umysłu i działania. Próby natomiast rozdzielania dyscyplin teoretycznych i praktycznych uznaje za nienaturalne i spowodowane grzechem pierworodnym, skazującym człowieka na poznawanie

22 BenedyktXVI, Fundamentem prawdziwej kulturyjestposzukiwanie Boga, (Paryż 12 września 2008), „L'Osservatore Romano” (wyd. polskie), 10-11 (2008), s. 16.

23 J. Ratzinger, Wiara w Piśmie i Tradycji. Teologiczna nauka o zasadach, tłum. J. Merecki, „Opera Omnia”, t. IX / 1, (red.) K. Góźdź, M. Górecka, Lublin 2018, s. 43.

24 Z. I. Kijas, Początek świata i człowieka, Kraków 2004, s. 126-143. 297-300.

25 Historia Teologii, t. I, Epoka patrystyczna, (red.) A. di Berardino, B. Studer, Kraków 2003, s. 163.

26 Tamże, s. 164.

27 Doświadczenie - tak, jak je rozumie tradycja chrześcijańska, mimo dość nieostrego pojęcia - pozostaje w ścisłej relacji do wiary i życia Kościoła, przyczyniając się jednocześnie do tego, aby teologia nie była czysto intelektualną lub erudycyjną aktywnością. J. Ratzinger, Wiara w Piśmie i Tradycji. Teologiczna nauka o zasadach, s. 79-93; J. Morales, Wprowadzenie do teologii, tłum. P. Rak, Kraków 2006, s. 197-219.

28 Historia Teologii, t. II, Epoka średniowieczna, tłum. W. Szymona, (red.) G. D’Onofrio, Kraków 2010, s. 179-180. 
fragmentaryczne. Dlatego teologię uznaje za jedyne miejsce i sposób osiągnięcia doskonałości teoretycznej oraz praktycznej ${ }^{29}$. Inną historią, w tym samym nurcie, jest średniowieczny woluntaryzm, podkreślający obraz Boga działającego - stwarzającego świat na podstawie swojej wolnej i niczym nieograniczonej woli $^{30}$ oraz rozstrzygnięcia poczynione $\mathrm{w}$ tej problematyce chociażby przez Jana Dunsa Szkota ${ }^{31}$. Wreszcie William Okham, zastanawiając się nad miejscem teologii wśród innych nauk, twierdzi, że nie będąc w tym sensie nauką jak inne dziedziny wiedzy, jest ona zarazem czymś więcej niż nauką, ponieważ jako rzeczywiste poznanie złożone, należy do porządku mądrościowego, w którym jej charakter praktyczny jest równie oczywisty, jak oczywiste są fakty interesujące nauki różne od teologii ${ }^{32}$.

Skąd zatem pomysł o pionierstwie Antonino Pierozziego oraz hiszpańskim kręgu „pierwszych teologów praktycznych” i czego nas uczy powyższa introspekcja? Okazuje się, że nie tylko filozofia Immanuela Kanta przyczyniła się do rozpatrywania praktycznego wymiaru wiedzy w ramach moralności i etyki ${ }^{33}$. Otóż do końca XVI wieku teologia moralna nie była odrębną dyscypliną, a właściwe jej problemy rozpatrywano w ramach teologii scholastycznej. Co ciekawe, teologia moralna oddziela się od dogmatyki wraz z wyodrębnieniem się mistyki (XVII), która tym samym, właśnie w kwestii praktycznego wymiaru teologii, nie powinna być całkowicie pomijana ${ }^{34}$. Wyodrębnioną już teologię

29 Przy tej okazji Bonawentura dokonuje analizy i oceny filozofii. Nie dyskredytuje jej, ale ukazując jej przydatność w chrześcijańskim zdobywaniu wiedzy - czego jedynym wyznacznikiem i wystarczającym jest Chrystus - dostrzega jej niewystarczalność. Krytykuje ciekawość filozofów i nastawienie scientia per scientia. Historia Teologii, t. II, Epoka średniowieczna, s. 364-368.

30 Tamże, s. 487-488.

31 Wola ludzkajest prowadzona niejako poznaniem, na podstawie którego dokonuje wyborów. Jeśli jej cel wyznacza zjednoczenie się z Dobrem Najwyższym, to na podstawie naturalnego poznania nie jest ona - jak twierdzi Jan Duns Szkot - wolna od błędów. Rozum bowiem nie poznaje w sposób doskonały bytu doskonałego, czyli Boga, aby możliwa była w oparciu o takie kryterium korekta wyborów, dokonywanych przez człowieka na podstawie wolnej woli. Bóg przychodzi jednak z pomocą przez Objawienie, które wprawdzie woli nie determinuje, ale też nie skazuje jej na konieczność ślepego przypadku, a nawet ryzyka błędu. Historia Teologii, t. II, Epoka średniowieczna, s. 490-491.

32 Tamże, s. 523-526.

33 Kant - zgodnie z duchem swojej epoki - odchodzi od kwestii metafizycznych, zastępując je moralnością (powinnością moralną), która - jego zdaniem - stanowi o wartości człowieka i jego odrębności od świata zwierzęcego. A. M. Kaniowski, Filozofia praktyczna Immanuela Kanta - jej sila i stabości, „Diametros” 2 (2004), s. 114-126.

34 Związek teologii moralnej z mistyką nie jest przypadkowy, ponieważ, o ile mistycy próbują zrozumieć, w jaki sposób zostaje przebóstwiona dusza bez naruszenia ludzkiej wolności, 
moralną zaczęto nazywać „praktyczną”35. Oddzielenie jednak teologii moralnej od dogmatyki przyniosło poważne szkody jednej i drugiej, przyczyniając się do marginalizacji teologii jako takiej ${ }^{36}$. Nie powstrzymało także protestanckiej „kanonizacji niesprawiedliwości”. Raczej nie do pominięcia w ramach teologii jako wiedzy praktycznej. U Lutra znika moment przygotowania do usprawiedliwienia, a głoszona przez niego bierność podmiotu w relacji do łaski, to w rzeczy samej negacja wolnej woli i zniesienie wolności ${ }^{37}$. W żadnym sensie nie spotyka się to $z$ autodeterminizmem o. Woronieckiego i dlatego skazane jest na deterministyczny obraz świata i człowieka. Reakcją na takie przewartościowanie może być już tylko indeterminizm. Tym bardziej totalny, im bardziej areligijny $^{38}$, co trudno uznać za zgodne $z$ tradycją chrześcijańską.

Zarysowane powyżej zmiany w epoce nowożytnej (zarówno w teologii jak i innych naukach) miały wpływ także na filozofię, która w XVIII wieku starała się rozwiązywać problemy moralne, dryfując w kierunku idealizmu i naturalizmu oraz redukując adekwatnie sumienie do świadomości lub do empirycznego faktu, sprowadzanego w zasadzie do kategorii psychologicznej. Ale i dokonujące się zmiany w filozofii wpływały na teologię ${ }^{39}$. Chodzi tu głównie o jej wciąż nieprzezwyciężony kryzys, spowodowany utratą charakteru mądrościowego

o tyle moraliści analizują prawo wieczne i prawo naturalne, określając charakter zobowiązania na podstawie poznania jednego i drugiego przy pomocy rozumu.

35 Nie należy zapominać o rozróżnieniu na teologię moralną uniwersytecką (akademicką) zajmującą się ogólnymi zasadami moralnymi; teologię moralną praktyczną lub kazuistyczną i jeszcze pośrednią - łączącą jedną i drugą. Uprawiający ją teologowie hiszpańscy - co ciekawe - jako podstawę traktują, integrującą złożenie bytu ludzkiego z duszy i ciała, rzeczywistość ludzkiej osoby, co rzutowało na ich rozumienie esse iagere. Według Francisco de Osuny zmysły sprowadzają się do władz, a te do tego centrum, które należy nazwać najtajniejszym i nienaruszalnym miejscem w duszy ludzkiej - sanktuarium sumienia, w którym dusza doświadcza działania rozumu i miłości przemieniającej. F. D. Osuna, Tercer Abecedario Espirytual, Madrid 1972, s. 140-149; Historia Teologii, t. IV, Epoka nowożytna, tłum. W. Szymona, (red.) G. Angelini, G. Colombo, M. Vergottini, Kraków 2008, s. 222-227.

36 Oile w średniowieczu stanowiła ona podstawę obrazu świata i człowieka; podejmowanych działań i rozwiązań przez człowieka w świecie, na podstawie zasad zawartych w Objawieniu, to obecnie ocenia się ją jako wiedzę marginalną. Historia teologii, t. IV, Epoka nowożytna, s. 480-483; B. Häring, Zasadnicza postać chrześcijańskiego życia. Teologia moralna ogólna, t. I, tłum. J. Klenowski, Poznań 1962, s. 27-62. Historia Teologii, t. IV, Epoka nowożytna, s. 40-47.

38 M.D. Chenu, Wybór pism, tłum. L. Rutkowska, W. Sukiennicka, Z. Włodkowa, Warszawa 1971, s. 228-246.

39 H.U.von Balthasar, Pisma wybrane, t. 1, Pisma filozoficzne, tłum. M. Urban, D. Jankowska, Kraków 2006, s. 37-65; K. Rahner, Pisma wybrane, t. 1, tłum. G. Bubel, Kraków 2005, s. 68-89. 
i rezygnacją z problemu obiektywnej prawdy. Praktyczna filozofia Immanuela Kanta, zastępująca klasyczną metafizykę powinnością moralną ${ }^{40}$, jest zarazem „dzieckiem” i kontynuacją tego kryzysu.

\section{Werytatywna korekta rozumu praktycznego}

Spróbujmy zatem określić problem teologii jako wiedzy praktycznej-dzisiaj, bez uproszczonego i sztucznego, a także redukcjonistycznego, przeciwstawiania teorii praktyce, czy choćby ich separowania. Dookreślenie „dzisiaj” wydaje się dość istotne nie tylko ze względu na wspomniany marksistowski przełom. Wielkim bowiem wyzwaniem wobec teologii okazuje się postmodernistyczne redefiniowanie rzeczywistości, sięgające podstaw bytu. Definiując go na podstawie chrześcijańskiej metafizyki, radykalnie rozmijamy się z przedstawicielami ideologicznej, genderowskiej nowomowy, której ponowoczesne propozycje wydają się szczególnie szeroko otwierać przysłowiowe wrota dokonującej się na naszych oczach „rewolucji kulturalnej”. Relatywizm przy tym zagrożeniu, jeszcze nie tak dawno stanowiący podstawowe zagrożenie wiary, okazuje się katarem wobec śmiertelnej choroby, co nie znaczy, że katar nie może się pojawić jako jeden z symptomów owej śmiertelnej choroby. Aby w ogóle odpowiedzieć na to wyzwanie potrzebne jest jasne i niebudzące wątpliwości kryterium ${ }^{41}$. Niewzruszony aksjomat wydaje się więc nieodzowny - w nauce chodzi przecież o prawdę!42.

Wiara nie może być sprowadzona tylko do wiedzy. Zwłaszcza wysoce teoretycznej, spekulatywnej33. Podobnie jak nie może się obyć bez problemu prawdy. W tym sensie teologia jako wiedza praktyczna, czyli na podstawie wiary określona postawa duchowa i wypływające z niej wybory, decyzje, to właściwe rozumienie niezbędnego w tym wydarzeniu udziału ludzkiego rozumu, objawienia i życia. W rzeczy samej oznacza to klucz personalistyczny, pozwalający właściwie - tzn. w sposób wyczerpujący - ująć współdziałanie rozumu i wolnej woli w człowieku. To współdziałanie należy rozumieć jako odkrywanie sensu ${ }^{44}$. To kwestia fundamentalna i tym samym najbardziej podstawowe zagadnienie

40 O. Höffe, Immanuel Kant, tłum. A. M. Kaniowski, Warszawa 2003, s. 234-235; B. Häring, Świętość a dobro. Wzajemny stosunek religii i moralności, Poznań 1963, s. 72-85.

41 H. U. von Balthasar, Teologika, 1 Prawda świata, tłum. J. Zychowicz, Kraków 2004, s. $35-74$.

42 K. R. Popper, Objective Knowledge - An Evolutionary Approach, Oxford, 1975, s. 19.

43 J. Ratzinger, Wiara w Piśmie i Tradycji. Teologiczna nauka o zasadach, „Opera Omnia”, t. IX / 2, s. 827-828; K. Rahner, Praxis des Glaubens. Geistliches Lesebuch, Freiburg - Basel - Wien 1984, s. 52-199.

44 K. Rahner, Pisma wybrane, t. 1, s. 168-180. 242-243. 
teologii jako wiedzy praktycznej. Dał temu wyraz Joseph Ratzinger pochylając się już nad pierwszym artkułem wiary, jednoznacznie określającym podejście człowieka do życia i jego oczekiwania wobec Tego, któremu się zawierza, tworząc szczególnego rodzaju relację ${ }^{45}$. Wszystko od tego wychodzi i ku temu ostatecznie zmierza, co zdaje się oddawać nie tylko zgrabna formuła: w teologii chodzi o ciebie ${ }^{46}$ ! W teologii jako wiedzy - w czym jej wymiar praktyczny jest nieodzowny - chodzi o to, aby w każdym ludzkim bólu, porażce i ocieraniu się lub wchodzeniu w śmierć był obecny Jezus w swojej śmierci na krzyżu (Bartnik swoją misję teologa chcial potwierdzać w odpowiedzi na pytanie zadane mu przez ks. Góździa). Chodzi również o to, aby Chrystus Zmartwychwstały był w każdym ludzkim zwycięstwie, radości i mimo grozy śmierci, w przekonaniu, że nie kończy i nie zamyka ona wszystkiego, ale otwiera coś, co jest od tego wszystkiego lepsze, ważniejsze i piękniejsze. Natomiast nie chodzi o to, aby się użalać pod krzyżem i zadziwić przed pustym grobem, przed którym przecież i tak nikt nie płacze; w jednym i drugim dostrzegając tylko - nawet jeśli bardzo wymowny - symbol. I to niezależnie od poziomu i sposobu tego użalania się ${ }^{47}$. Paul Ricoeur, uznając symbol za podstawowy w języku religijnym, ma niewątpliwie wiele racji, ale praktyczny wymiar wiedzy teologicznej pokazuje nam konieczność przeżycia - doświadczenia tego, co symbol wyraża, aby teologia nie zatrzymała się tylko na języku.

W tej kwestii fundamentalnej - odkrywania głębokiego sensu egzystencji - teologia jako wiedza, nie może pozwolić sobie w świecie post-prawdy i redefinicji podstaw bytu, na jakiekolwiek osłabienie nowotestamentowego, kulminacyjnego momentu sporu o prawdę ${ }^{48}$. Chodzi o dialog Jezusa z Piłatem na pretorium, kiedy mówi: „Ja się na to narodziłem i na to przyszedłem na świat, aby dać świadectwo prawdzie" (J 18, 37). Z doprowadzonymi do końca konsekwencjami tych słów ${ }^{49}$ ! W tym miejscu i od tego momentu, prawda

45 J. Ratzinger, Wiara w Piśmie i Tradycji. Teologiczna nauka o zasadach, „Opera Omnia”, t. IX / 1, s. 47-48; tenże, W rozmowie z czasem, „Opera Omnia”, t. XIII / 2, Lublin 2017, s. $610-621$.

46 T. Węcławski, W teologii chodzi o ciebie. Przewodnik po źródłach $i$ skutkach teologicznej wyobraźni, Kraków 1995; H. U. von Balthasar, Teodramatyka, 2 Osoba dramatu, cz. I, s. $322-332$.

$47 \quad$ J. Szymik, O teologii dzisiaj, s. 176. 193-194; T. Halik, Co nie jest chwiejne. Labiryntem świata z wiara $i$ wątpliwościami, tłum. J. Zychowicz, Kraków 2004, s. 94-95; H. U. von Balthasar, Teodramatyka, 1 Prolegomena, s. 15-22.

48 J. Ratzinger, Wiara w Piśmie i Tradycji. Teologiczna nauka o zasadach, „Opera Omnia”, t. IX / 2, s. 829.

49 J. Ratzinger, Europa - dziedzictwo zobowiąujace chrześcijan, tłum. L. Balter, [w:] Kościót - ekumenizm - polityka, „Communio” - kolekcja 5, Poznań 1990, s. 263; tenże, Prawda wartości - władza. Kiedy społeczeństwo można uznać za pluralistyczne, tłum. G. Sowiński, 
przestaje być domeną filozofów. Staje się fundamentem życia w takim sensie, że pozbycie się jej pociąga za sobą odrzucenie Jezusa; wyeliminowanie chrześcijaństwa - w znaczeniu jak najbardziej praktycznym. I odwrotnie, potrzeba ogłoszenia Jezusa; Jego obecności i wystarczalności w odpowiedzi na najtrudniejsze pytania egzystencjalne, domaga się obiektywnego i wszystkich zobowiązującego, charakteru prawdy ${ }^{50}$. Dlatego słowa z Equangelii Janowej: „Ja jestem drogą, prawdą i życiem” (J 14, 6), należy uznać za najbardziej trafną i najkrótszą z możliwych, definicję teologii jako wiedzy praktycznej!

Teologii jako wiedzy praktycznej, nie wolno więc rozumieć jako utylitarno-instrumentalnego funkcjonalizmu ${ }^{51}$. Jej wyznacznikiem i pełnym określeniem jest skoncentrowanie się na odniesieniu człowieka do Boga, w czym wzorem i przykładem pozostaje Jezus Chrystus ${ }^{52}$. Z kolei najlepszym sposobem realizacji tego odniesienia i tym samym praktycznego wymiaru teologii, jest naśladowanie Chrystusa ${ }^{53}$. W takiej perspektywie i tym samym w rzeczonym momencie i miejscu, jakim jest pretorium Piłata, prawda to miłość. Konieczną perspektywą rozpatrywania tego zagadnienia powinna być objawiona prawda o Trójcy Świętej. I w tym kontekście oraz w problematyce praktycznego wymiaru teologii, dobrze będzie ponownie przywołać ks. prof. Czesława Bartnika, który często powtarzał, że chrześcijanie dopóty nie uporają się z problemami pojawiającymi się w przestrzeni wzajemnych odniesień rozumu, wiary i życia (dotyczy to w takim samym stopniu teologów), dopóki tajemnica Trójcy Świętej nie przestanie być traktowana jako wysoce teoretyczna (pojawiają się również określenia: abstrakcyjna) prawda wiary. Co to oznacza i do czego zobowiązuje?

\section{Miłość jako zasada porządkująca odniesienia między poznaniem i działaniem}

Postawmy jeszcze dwa - w związku z tym - pytania: Czy różne określenia miłości nie są w rzeczywistości różnymi, ale określeniami tego, co miłością tak

Kraków 1999, s. 32-35; A. D. Sacharow, Mein Land und die Welt, Wien 1972, s. 82; P. Nitecki, Quod est veritas. Spotkanie z Jezusem w pretorium Piłata, „Życie i Myśl” 25 (2009), s. 74; J. A. Allen, Irreligion. A Mathematician Explains Why the Arguments for God Just Don't App Up, New York 2009.

50 J. Ratzinger, Wiara w Piśmie i Tradycji. Teologiczna nauka o zasadach, „Opera Omnia”, t. IX/1, s. 46.

51 J. Babiński, Teologia życia. Próba reinterpretacji dorobku ks. Franciszka Sawickiego, Pelplin 2013, s. 440.

52 H. U. von Balthasar, Teologika, 2 Prawda Boga, tłum. J. Zychowicz, Kraków 2004, s. 61-116.

53 A. Nossol, Teologia blizsza życiu, s. 15-208. 337-396. 
naprawdę nie jest ${ }^{54}$ ? Jakie kryterium potrzebne jest, aby - mimo trudności - ten problem jakoś rozwiązać? ${ }^{55}$ Trudności te dostrzegamy zwłaszcza w podążaniu przy takim zamiarze - pod prąd wielowiekowej tradycji rozpatrywania miłości (eros i agape $)^{56}$, co może być zrozumiane jako wielce pretensjonalne, o ile nie karkołomne. Nie pozostaje jednak zupełnie osamotnione w chrześcijańskiej literaturze filozoficznej i teologicznej ${ }^{57}$. Niemniej teologia, w swoim praktycznym wymiarze, może być bardzo dobrą okazją do uporządkowania tych kwestii ${ }^{58}$. Oczywiście na podstawie reinterpretacji, jakiej dokonuje chrześcijaństwo, pamiętając chociażby o drodze, którą przebył św. Augustyn ${ }^{59}$, dochodzący do caritas, przez nieodpowiadające miłości doświadczenie cupiditas, a nawet amor. Przypomnijmy, Augustyn charakteryzujący się trynitarną perspektywą w swojej teologii, której nie powinno się ograniczać tylko do jego dzieła De Trinitate ${ }^{60}$.

\section{Boże prawo a miłość}

Skąd pomysł zainteresowania prawem w systematycznej refleksji na temat miłości? Dyktują to słowa Listu do Rzymian, zgodnie z którymi „miłość jest doskonałym wypełnieniem Prawa" $(13,10)$. Poza tym praktyczny charakter wiedzy teologicznej, której, po pierwsze, nie wolno się uchylać przed refleksją wiary na temat Bożego prawa ${ }^{61}$, a po drugie, w związku z tym pominąć bardzo istotnego wątku w Nowym Testamencie ${ }^{62}$. Oczywiście nie bez konotacji

54 R. Laurentin, Nowe wymiary miłości, tłum. M. Bocheńska, Warszawa 1977, 5-36; A. Andrzejuk, Franciszek Sawicki: Filozofia mitości, [w:] Metafizyka obecności. Wstęp do teorii relacji osobowych, Warszawa 2012, s. 343-344.

55 C. G. Andrade, Boskie atrybuty w świetle nauki o Trójcy Świętej, tłum. G. Ostrowski, Poznań 2003, s. 31-32.

56 C. Lindberg, Historia miłości w zachodnim chrześcijaństwie, tłum. M. Höffner, Kraków 2012.

57 F. Sawicki, Filozofia mitości, Poznań 1937, s. 8.

58 B. Häring, Z miłości ku miłości. Teologia moralna szczegółowa, cz. I, tłum. J. Klenowski, Poznań 1963, s. 86-102; K. Rahner, Praxis des Glaubens. Geistliches Lesebuch, s. 200-366.

59 J. Ratzinger, Lud i Dom Boży w nauce św. Augustyna o Kościele. Rozprawa doktorska oraz inne opracowania nauki Augustyna i teologii ojców Kościoła, „Opera Omnia”, t. I, tłum. W. Szymona, (red.) K. Góźdź, M. Górecka, Lublin 2014, s. 486-490.

60 Św. Augustyn, Solilokwia, I, 1, tłum. A. Świderkówna, [w:] tenże, Dialogi filozoficzne, Kraków 1999; tenże, Państwo Boże, tłum. W. Kubicki, Kęty 1998, 11, 9, 10; tenże, O Trójcy Świętej, tłum. M. Stokowska, Kraków 1996, 15, 28, 51.

${ }_{61}$ J. Ratzinger, Lud i Dom Boży w nauce św. Augustyna o Kościele. Rozprawa doktorska oraz inne opracowania nauki Augustyna i teologii ojców Kościoła, s. 373-377.

62 H. Merklein, Jesu Botschaft von der Gottesherrschaft, Stuttgart 1983, s. 93. 
starotestamentowych ${ }^{63}$. Mamy tu na myśli spór Jezusa z faryzeuszami o interpretację prawa, który zaprowadził Go przed Wysoką Radę, na pretorium Piłata i na krzyż ${ }^{64}$ W drodze tej nie sposób pominąć problemu miłości i prawdy. Jak się bowiem okazuje, próba pominięcia miłości i prawdy w kwestii prawa, prowadzi nie tylko do problemów z prawem - niejednokrotnie bardzo poważnych - ale również do poważnych błędów w jego rozumieniu, co jest bardzo mocno z tym pierwszym powiązane.

Wróćmy do zasygnalizowanego sporu Jezusa z faryzeuszami o interpretację prawa i praktycznego w tym względzie znaczenia teologii. Werytatywny obiektywizm w Jezusie Chrystusie, porównującym swoich adwersarzy do „grobów pobielanych" (Mt 23, 27), nie pozwala pominąć ludzkiej podmiotowości, co $z$ kolei bardzo angażuje miłość. Otóż w tym sensie faryzeusze chcą być wierni prawu, ale niekoniecznie widzą potrzebę miłości. Zwłaszcza tak daleko posuniętej, jak bardzo obowiązujące powinno być prawo i zobowiązująca prawda ${ }^{65}$. Brak ten jednak powoduje uszczerbek w prawie i w sprostaniu zobowiązaniom wobec niej ${ }^{66}$. Uwidacznia się to na pretorium - o czym była mowa. Zaangażowanie miłości przez Jezusa, czyli powiązanie jej z prawem i prawdą, prowadzi do uwewnętrznienia prawa, co Paweł interpretuje posługując się stoicką koncepcją sumienia - nie bez utrzymania zewnętrznego pochodzenia prawa, czyli od Boga ${ }^{67}$. Inaczej mówiąc, harmonia autonomii i heteronomii prawa, bez

63 R. Brague, La Sagesse du monde. Histoire de l'expérience humaine de l'univers, Paryż 1999, s. 201-202.

64 M.S. Wróbel, Antyjudaizm a Ewangelia wedtug św. Jana. Nowe spojrzenie na relację czwartej Ewangelii do Judaizmu, Lublin 2005, s. 147-163; H. Langkammer, Teologia biblijna Starego $i$ Nowego Testamentu, Legnica 2007, s. 290-291; R. P. Booth, Jesus and the Laws of Purity: Tradition History and Legal History in Mark 7, Trowbridge 1986, s. 219; W. Chrostowski, Między Synagogą a Kościołem. Dzieje św. Pawła, Kraków - Ząbki 2015, s. 32.

65 T. Kazen, Jesus, Scripture and Paradosis: Response to Friedrich Avemarie, [w:] The New Testament and Rabbinic Literature, (red.) R. Biringer, F. G. Martinez, D. Pllefeyt, P. J. Tomson, Boston - Leiden 2010, s. 288; F. Rosenzweig, Gwiazda Zbawienia, tłum. T. Gadacz, Kraków 1998, s. 229.

66 Ostateczne spełnienie się chrześcijanina w Bogu nie ogranicza się jedynie do jego wymiaru poznawczego, ale rozciąga się na jego sferę uczuciową. Przede wszystkim angażuje ludzką wolę. Według św. Augustyna natura miłości jest raczej wolitywna, a wola - zależnie od swego zwrócenia - ku dobru (recta voluntas) lub ku złu (perversa voluntas). Augustyn, O Trójcy Świętej, XV, 21, 45.

67 J. Taubes, Die politische Theologie des Paulus, Monachium 1993, s. 36; Z. W. Falk, Law and Religion. The Jewish Experience, Jerozolima 1981, s. 66; Apokalipsa Barucha Syryjska, tłum. J. Woźniak, [w:] Apokryfy Starego Testamentu, (red.) R. Rubinkiewicz, Warszawa 1999, s. 407-442; Owidiusz, Metamorfozy, tłum. A. Kamieńska, S. Stabryła, Wrocław 1995, VII, 20; Rękopisy znad Morza Martwego. Qumran, tłum. P. Muchowski, Kraków 2000, s. 22-23; Augustyn, Przeciw Sekundynowi, tłum. J. Sulowski, Warszawa 1999; 
nadmiernego podkreślania jednej kosztem drugiej, jest najlepszym kryterium jego rozumienia i najlepszą zasadą jego funkcjonowania. Przy czym najbardziej skuteczną tego podstawą jest miłość, wyrażająca wartość prawdy w słowach: „Nie przyszedłem [prawa] znieść, ale wypełnić” (Mt 5, 17) ${ }^{68}$. Dostrzegają to już Justyn i Ireneusz, podkreślając, że „dawne prawo wypełnia się w miłości”, a „wpatrujący się w Boga jest najbardziej zdolny do miłości”. Szczególnie Justyn zdaje się dostrzegać i zarazem podkreślać związek miłości, prawdy i prawa, kiedy zastanawiając się nad dowodami na prawdziwość Ewangelii wskazuje nie tylko na - jak to określa - „nieprzeciętność” chrześcijaństwa, ale wręcz - w porównaniu chociażby z myślą starogrecką, w której przecież dobrze się orientował - jego doskonałość. W jego przekonaniu wynika ona z prawa posuniętego aż do miłości nieprzyjaciól ${ }^{69}$.

\section{Miłość jako caritas}

Caritas w najgłębszym, chrześcijańskim sensie, nie może być ograniczona tylko do dobroczynności. Choć - właśnie jako caritas, czyli dar ${ }^{70}$, który ma na wskroś praktyczny charakter; konkret i związany jest z gotowością na wyrzeczenie, nawet cierpienie - nie może z dobroczynności się zwolnić. Chodzi o odkrycie, dotarcie do fundamentu, źródła, z którego wypływająca woda jest czysta ${ }^{71}$. I Augustyn jest najlepszym przykładem takiej drogi-czym w rozumieniu chrześcijańskim jest miłość. Najlepszym sposobem i zarazem urzeczywistnieniem takiego rozumienia oraz kochania jest właśnie rzeczywistość Trójejedynego Boga, która pozwala nam również rozprawiać się z tym, co miłością nie jest ${ }^{72}$. Niezależnie od częstotliwości i ilości przywoływanych, fałszywych określeń, jak też poszukiwania wyrafinowanych argumentów. Poza tym rzeczywistość, która weryfikuje samą teologię w jej umiejętności refleksji

\footnotetext{
A. Paciorek, Człowiek bez Chrystusa w soteriologii Listu św. Pawła do Rzymian, Tarnów 1995; M. Rosik, Kościót a synagoga (30-313 po Chr.) na rozdrożu, Wrocław 2016, s. 94-95.

68 H. Waldenfels, O Bogu, Jezusie Chrystusie i Kościele - dzisiaj, s. 246.

69 Historia Teologii, t. I, s. 144-145.

70 J. Ratzinger, Wiara w Piśmie i Tradycji. Teologiczna nauka o zasadach, „Opera Omnia”, t. IX/1, s. 49.

71 A. Štrukelj, Teologia i świętość, tłum. M. Jagodziński, Lublin 2010, s. 199-214.

72 J. Daniélou, Trójca Święta i tajemnica egzystencji. Znaki świątyni czyli obecności Boga, tłum. M. Tarnowska, Kraków 1994, s. 53-60; G. Greshake, Wierzę w Boga Trójjedynego. Klucz do zrozumienia Trójcy Świętej, tłum. W. Szymona, Kraków 2001; M. Jagodziński, Węzłowe zagadnienia chrystologii komunijnej, Radom 2013, s. 108-144.
} 
na temat miłości, co przesądza o jej praktycznym charakterze ${ }^{73}$. Nie zagłębiając się w scholastyczne spekulacje, które mogłyby nas zatrzymać właśnie w bardzo teoretycznych rozważaniach, wypada stwierdzić, że relację miłości Osób Bożych do siebie; Ich oddanie, powierzenie i przyjęcie, trudno rozpatrywać jako coś teoretycznego ${ }^{74}$. Zwłaszcza kiedy są one podstawą odniesienia człowieka do Boga, ponieważ - jak wynika z Modlitwy Arcykapłańskiej Jezusa (w Wieczerniku) - Bóg kocha człowieka taką samą miłością jak swojego Jednorodzonego Syna $(17,23)$. To informacja oszałamiająca, o ile nie szokująca, kiedy zdobędziemy się na dosłowne jej potraktowanie, czyli wyjście z kręgu teoretycznych spekulacji na rzecz praktycznego przecież zobowiązania. Zdanie Benedykta XVI z encykliki Deus caritas est: „Jeśli widzisz miłość, widzisz Trójcę”75, wolno - jak się wydaje - nieco odwrócić: Dopiero w prawdzie o Trójcy wiesz, czym jest naprawdę miłość.

Prawda w Jezusie Chrystusie weryfikuje się i potwierdza w miłości ${ }^{76}$. Możliwe są bowiem różne drogi do tej samej prawdy i w samej teologii niejednokrotnie spotykamy się z tego rodzaju argumentacją. Ale miłość jest zawsze podążaniem w tym samym kierunku ${ }^{77}$. Słabość Boga jest Jego siłą ${ }^{78}$, a najpiękniejszym objawieniem prawdy o Nim jest Jego miłość. Wróćmy jeszcze do św. Augustyna. Pochylając się nad słowami Listu św. Pawła do Efezjan, zalecającego zachowanie jedności, z akcentem na słowa: „Jeden jest Pan, jedna wiara, jeden chrzest" (4, 5), biskup Hippony dokonuje przesunięcia akcentów. Otóż, ten niestrudzony poszukiwacz prawdy, nie odnosi się w pierwszym rzędzie do „jednej wiary” (należy ją rozumieć jako systematyczną refleksję na drodze do prawdy). Wpłynęly na to najprawdopodobniej kontrowersje z donatystami, powołującymi się na ten sam tekst Pisma Świętego, ale już bez konsekwencji w jedności wiary i takich samych wniosków w teologii. Można sobie jednak

73 „Wiara jest życiem, gdyż jest relacją; jest poznaniem, które staje się miłością, i miłością, która pochodzi z poznania i do niego prowadzi”. J. Ratzinger, Wiara w Piśmie $i$ Tradycji. Teologiczna nauka o zasadach, „Opera Omnia”, t. IX/2, s. 829; W. Przygoda, Uwierzyć miłości, by stać się świadkiem mitości, [w:] Perspektywy wiary, s. 83-90.

74 M. Kozak, Kościót jako communio wedtug Gerarda Philipsa, Lublin 2003, s. 54; A. Czaja, Jedna osoba w wielu osobach. Pneumatologiczna eklezjologia Heriberta Mühlena, Opole 1997.

75 Bendykt XVI, Deus caritas est, Watykan 2005, 19.

76 H. U. von Balthasar, Teologika, 2 Prawda Boga, s. 27-33.

77 R. Laurentin, Nowe wymiary mitości, s. 54-66.

78 Być silnym, żeby być lagodnym, Z s. Małgorzata Chmielewska rozmawia Ewa Kiedio, „Więź” LVI (2013) nr 3 [653], s. 18-25; https://tischner.pl/s-malgorzata-chmielewska -slabosc-boga-jest-jego-sila/. 
wyobrazić inne kontrowersje. Stąd Augustyn jako podstawowy warunek jednej wiary i prawdy zarazem - niepodzielnej, ukazuje właśnie caritas $^{79}$.

Gdzie tkwi istota problemu? Nie chodzi przecież tylko o dowodzenie, przekonywanie o praktycznym wymiarze wiedzy teologicznej. W teologii właśnie i przede wszystkim w Ewangelii, chodzi o to, aby prawdy - zarówno w jej poszukiwaniu jak i przepowiadaniu (świadectwie) - nie ograniczać do teoretycznych, uczonych rozważań. Choćby z tego tytułu, że nie przyczyniają się one realnie do sprawiedliwego podzielenia chleba ${ }^{80}$. Przyczynia się do tego caritas, która jest najbardziej sprawiedliwa, ponieważ jest realizacją zobowiązania wynikającego z takiej samej miłości, jaka wiąże Ojca z Synem. Ten praktyczny wymiar leży u podstaw kształtowania się wiary - chrześcijańskiego Credo w perspektywie objawionej prawdy ${ }^{81}$. Wystarczy wspomnieć celebrację chrztu, udzielanego niemalże od początku w imię Trójcy, stanowiącego centrum chrześcijańskiego życia, a nie przestrzeń wysoce teoretycznych, intelektualnych poszukiwañ ${ }^{82}$. W tym sensie chrześcijaństwo to nie tyle znajomość dogmatów, ile raczej miłość, która rodzi się w spotkaniu z Bogiem - Prawdą. Rodzi się, ponieważ prawda ta nie jest tylko informacją, choćby wyjaśniającą najgłębszy sens ludzkiego życia, ale posuwa się aż do Wcielenia, aby Jego miłość stała się ciałem pośród nas, a więc czymś bardzo konkretnym i zarazem praktycznym.

\section{Mądrość (życia) realizująca się przez świętość}

Przeciwstawianie sobie wiedzy i mądrości, choć wygląda absurdalnie, ma długą oraz złożoną historię $e^{83}$. Podobnie jak przeciwstawianie wiedzy teoretycznej i praktycznej, czy choćby ich separowanie lub jednostronne ujmowanie. Wydaje się, że pochylenie się nad kwestią praktycznego wymiaru teologii, pozwala odkryć szczególną wartość i trudne do przecenienia znaczenie teologii w ogóle. Jest ona wiedzą szczególną, także przez to, że właściwie rozumiana i uprawiana, wymyka się wszelkiej parcjalności, ponieważ rości sobie pretensje do usensowienia wszystkiego ${ }^{84}$. Inaczej mówiąc - jak ujął to Jerzy Szymik odróżniając mądrość od wiedzy - mądrość nie tylko wie, ale również wie, po co wie

79 Augustyn, O Trójcy Świętej, XIII, 2, 5.

80 J. Ratzinger, Wiara w Piśmie $i$ Tradycji. Teologiczna nauka o zasadach, „Opera Omnia”, t. IX/1, s. 50-51; tenże, Jezus z Nazaretu, cz. I, tłum. W. Szymona, Kraków 2007, s. 40.

81 J. Ratzinger, Wiara w Piśmie i Tradycji. Teologiczna nauka o zasadach, „Opera Omnia”, t. IX/2, s. 830.

82 R. Kuligowski, Jak żyć wiara, [w:] Perspektywy wiary, s. 134.

83 J. Szymik, O teologii dzisiaj, s. 133-143.

84 Być dla, czyli myśleć sercem. Z ks. biskupem A. Nossolem rozmawia ks. J. Szymik, Katowice 1999, s. 72, 94, 130. 
i co zrobić z tym, co się wie. Nie tylko stawia pytanie jak żyć, ale odpowiada na nie ${ }^{85}$. Ten wymiar mądrościowy teologii, podobnie jak praktyczny, uczy nas niewątpliwie wielkiej pokory, ale jednocześnie uczy czegoś, co zatraciła już dawno filozofia. Tylko dobrze rozumiana i uprawiana teologia radzi sobie z interpretacją złożonej rzeczywistości, którą ukazuje Biblia. Do końca nie radziła sobie z nią myśl judaistyczna, zbyt mocno narzucając jedność. Podobnie jak starogrecka, przywiązana do dualizmu. Oczywiście teoria i praktyka; wiedza i mądrość, to jeden z wielu przejawów owej złożoności, jednak bardzo dobrze pokazujący, którędy prowadzi droga do pogodzenia ze sobą, a w Jezusie Chrystusie do zjednoczenia, „świata Boga” i „świata człowieka”. Na pewno nie zbliża do tego separowanie tych rzeczywistości od siebie, a tym bardziej przeciwstawianie ich sobie, jak próbuje się niejednokrotnie separować lub przeciwstawiać teorię i praktykę oraz wiedzę i mądrość.

Stąd teologia, jako wiedza praktyczna, to prawdziwa mądrość i to w pełni „wiedza pełna”, ponieważ obejmująca doczesność i wieczność. W tym sensie starogrecki środek do szczęścia ${ }^{86}$, czyli filozofia (umiłowanie mądrości) jawi się jako niewystarczający, czyli niepełny ${ }^{87}$. Tym bardziej „ułomna” wydaje się filozofia, która traci charakter mądrościowy i zainteresowanie prawdą (o ile jeszcze pozostaje filozofią). Całkowicie jednak od filozofii odejść nie można ${ }^{88}$. Choćby dlatego, aby pokazując jej przydatność, zdawać sobie sprawę z jej niewystarczalności ${ }^{89}$. Dlatego wróćmy jeszcze do Bartnika i jego odpowiedzi na pytanie o lęk przed śmiercią. Mądrość „wystarczająca” nie cofa się przed tym egzystencjalnym lękiem, ponieważ nieprzezwyciężony kładzie się on cieniem na wszystkich dokonaniach człowieka - także na jego poznaniu prawdy i jego miłości. Filozofia z takim lękiem sobie nie radzi. Podobnie jak - po swoim rozejściu się z prawdą i utratą mądrościowego charakteru - z ostateczną podstawą

85 J. Szymik, O teologii dzisiaj, s. 134.

86 J. Paszyński, Eudajmonizm, t. 3, Lublin 2002, s. 306-307.

87 J. Ratzinger, Rozumienie objawienia i teologia historii wedlug Bonawentury. Rozprawa habilitacyjna i studia nad Bonawentura, s. 356-359.

88 M. Urban, Hans Urs von Balthasar - otwarty rozum, [w:] H. U. von Balthasar, Pisma wybrane, t. 1, Pisma filozoficzne, tłum. M. Urban, D. Jankowska, Kraków 2006, s. 9-12.

89 F. Sawicki, Filozofia życia, Poznań 1936, s. 13-14; tenże, Osobowośćchrześcijańska, Kraków 1947, s. 36; tenże, Życie ludzkie, Poznań 1936, s. 10-181; tenże, Die Wahrheit des Christentums, Paderborn 1918, s. 231; tenże, Die Gottesbeweise, Paderborn 1926, s. 198-202; tenże, Św. Augustyn pierwszym czlowiekiem nowożytnym, [w:] Święty Augustyn, (red.) S. Bross, Poznań 1930, s. 232; P. Fransen, Das neue Sein des Menschen in Christus, [w:] Mysterium Salutis, (red.) J. Fejner, M. Löhrer, t. 4, Einsiedeln 1973, s. 921-983; J. Babiński, Teologia życia, s. 433-450. 
natury rzeczy ${ }^{90}$. Nie zabezpiecza skutecznie przed rozpaczą i nie ugruntowuje nadziei ${ }^{91}$. Może dlatego Bartnik chciał się spotkać z kapłanami egipskimi, a nie np. z Platonem i Arystotelesem, którym - najogólniej rzecz ujmując - teologia chrześcijańska więcej zawdzięcza, niż kapłanom staroegipskim. Ale pojawia się pewien - rzadko przez archeologów i historyków (egiptologów) - dostrzegany problem. Jakie musiało być bogactwo ducha ludzi, którzy pozostawili po sobie takie dzieła materialne? ${ }^{92}$

Trzeba je zestawić z bogactwem, jakie umożliwia chrześcijaństwo. Jan Szkot Eriugena, np. ukazywał Piotra jako wzór wiary i postępowania, a Jana jako symbol kontemplacji i wiedzy. Snując refleksję nad biblijną sceną wejścia tych dwóch do grobu, do którego Piotr wchodzi pierwszy, czyli przed Janem, znajdującym się przy grobie wcześniej, niż Piotr, podkreśla potrzebę „oczyszczonej kontemplacji”. Pozwala ona lepiej przenikać tajemnice Pisma, które jest u tego samego autora symbolem grobu Chrystusa ${ }^{93}$. Z kolei oczyszczenie jest symbolem działania. Nie jest zatem tak, że jedno rozwija się kosztem drugiego, ale jedno dzięki drugiemu. Prawdziwa mądrość wyraża się w poznawaniu i kochaniu; w gromadzeniu wiedzy i działaniu. Oznacza to, że prawdziwa mądrość potrzebuje wiedzy i świętości ${ }^{94}$, co osiągalne jest przez kontemplację i działanie - ora et labora według patrona Europy. Kulturę chrześcijaństwa i Europy, przez całe wieki kształtowano w oparciu o regułę św. Benedykta ${ }^{95}$. Do tej kultury, łagodzącej - ale nie rezygnującej - ze wschodniego, surowego monastycyzmu, należą także bardzo praktyczne rozwiązania ${ }^{96}$, stanowiące podwaliny ważnej

90 J. Ratzinger, Wiara w Piśmie i Tradycji. Teologiczna nauka o zasadach, „Opera Omnia”, t. IX/1, s. 47-48.

91 F. Nietzsche, Poza dobrem i ztem, tłum S. Wyrzykowski, Warszawa 1907; tenże, Niewczesne rozważania, tłum L. Staff, Warszawa 1912; A. Schopenhauer, O wolności ludzkiej woli, tłum. A. Stögbauer, Warszawa 1991; J.-P. Sartre, Mdłości, tłum. J. Trznadel, Warszawa 1974, s. 126-127; tenże, L’etre et le ne`ant, Paris 1979; J.-P. Sartre, B. Le`vy, Czas nadziei, tłum. H. Puszko, Warszawa 1996.

92 W. Bator, Myśl starożytnego Egiptu, Kraków 1993.

93 Historia Teologii, t. II, Epoka średniowieczna, s. 7-8.

94 Duch Święty daje jedność scientia et sapientia. On jest podstawą i zarazem sprawcą tego, co w teologii wielkie i genialne, ważne i piękne. Historia Teologii, t. II, Epoka średniowieczna, s. 367-368; A. Štrukelj, Teologia i świętość, 9-21; B. Häring, Świętość a dobro, s. 11-38; H. U. von Balthasar, Teologika, 3 Duch Prawdy, tłum. J. Zychowicz, Kraków 2005, s. 55-90.

95 P. Kiejkowski, Trzy stowa papieża Benedykta XVI dla Europy. W trosce o integralny humanizm, s. 99.

96 Historia Teologii, t. II, Teologia średniowieczna, s. 51-53; B. Kumor, Historia Kościoła. Czasy nowożytne. Roztam w chrześcijaństwie zachodnim, t. 5, Lublin 1984, s. 212-213; V. Despres, Początki monastycyzmu, t. 2, tłum. J. Dembska, Kraków 1999, s. 256. 
w każdej cywilizacji ekonomii i gospodarki. Otóż klasztory na Zachodzie, zorganizowane na wzór niemalże idealnego społeczeństwa, funkcjonowały jak dobrze zarządzane firmy ${ }^{97}$. Do propozycji Jerzego Szymika, aby teologia była nie tylko „dyskutująca”, ale i „klęcząca”, należy dodać także, oby jak najczęściej - w tym benedyktyńskim sensie - była „działająca” ${ }^{98}$. Oczywiście w takiej perspektywie działanie trudno odrywać od świętości, rozumianej w chrześcijaństwie jako nie tylko najbardziej skuteczny sposób podążania do szczęścia. I to wiecznego. To w najgłębszym sensie szczęście w podążaniu, co w gruncie rzeczy, nie tyle odwraca perspektywę starogreckich mędrców, ile raczej ją uzupełnia w sposób, który na gruncie ich tradycji nie był możliwy.

\section{Zakończenie}

Naszą refleksję na temat teologii jako wiedzy praktycznej zdawały się wyznaczać dwa podstawowe problemy. Bardziej zewnętrzny i wewnętrzny, czyli konkretny kontekst chrześcijańskiego świadectwa i potrzeba sensu ${ }^{99}$. Jak w każdej epoce to podstawowe wyzwanie wobec teologii. Nie zmienia go, ale tylko podkreśla, nazywanie przez niektórych - np. przywoływanego Wojciecha Roszkowskiego - współczesnego nam wyzwania jako wielki kryzys ${ }^{100}$, a nawet zmierzch dotychczasowego radzenia sobie z nim. Takiego wyzwania nie podejmują dziś - i nie tylko dziś - nauki szczegółowe. Niekompetentna okazuje się także filozofia. Przede wszystkim z powodu głębokiego kryzysu, spowodowanego utratą charakteru mądrościowego i rezygnacją z problemu prawdy, nie wypełnia ona w żadnym sensie pojawiającej się głębokiej wyrwy. Dosłownie luki, która zagraża naszej cywilizacji. W rzeczywistości bowiem nie mamy do czynienia $z$ jakąkolwiek pustką, nawet brakiem - przynajmniej w sensie fizycznym, ale $z$ zajęciem tego „miejsca” przez to, co jest antydogmatyczne, a więc zwrócone przeciwko prawdzie i w konsekwencji przeciwko cywilizacji. Czy w tym fundamentalnym sporze, teologia jako wiedza praktyczna, może odegrać jakąś rolę?

97 F. Koneczny, Cywilizacja Bizantyńska, Londyn 1973, s. 194; A. Solignac, P. Massein, J. Gribomont in., Monastycyzm. Historiai iduchowość, tłum. D. Stanicka-Apostoł, Kraków 2002, s. 119-120.

98 J. Szymik, O teologii dzisiaj, s. 105.

99 Wydaje się to być odnośne do rozpatrywanej przez Ratzingera, spotykającej się ze sobą obiektywności i subiektywności oraz relacji podmiotu i przedmiotu. Powołując się na Einsteina, jako zadziwiające, ale również prawidłowe, ukazuje on zgodność świata powstałego w czystej świadomości podmiotu z rzeczywistością. J. Ratzinger, Wiara w Piśmie i Tradycji. Teologiczna nauka o zasadach, „Opera Omnia”, t. IX/1, s. 46.

100 W. Kasper, Rzeczywistość wiary, tłum. J. Piesiewicz, Warszawa 1979, s. 9-12. 58-62. 
Pytanie raczej retoryczne. I przesądzają o tym dwa, dość oczywiste argumenty. Po pierwsze, chodzi wciąż o wiedzę. Stąd artykuł na ten temat nie został pozbawiony systematycznych rozważań, określanych często jako teoretyczne. Wiedza natomiast jest wartościowa, prawdziwa - co zahacza już o tautologię kiedy liczy się z prawdą; uznaje jej krytyczną funkcję wobec wszystkich swoich osiągnięć na podstawie rozumu. Teologia - we współczesnym, niejednoznacznym i postmodernistycznym, rezygnującym z problemu prawdy, świecie - jako jedyna z prawdy nie rezygnuje. Co więcej, nie jest to w ogóle możliwe, ponieważ służba prawdzie właśnie, stanowi jej sine qua non.

Drugi argument, który wolno - jak się wydaje określić także mianem kntekstualnego - to współczesne, również w nauce, przewartościowanie na korzyść praktycznej wartości ludzkiej wiedzy i jej osiągnięć. To przewartościowanie na korzyść agere idzie dziś tak bardzo daleko, że staje się niekorzystne w poznawaniu złożoności i bogactwa, tudzież piękna oraz zachwycającej tajemnicy (misterium) ludzkiego esse. Temu przewartościowaniu, a właściwie zaburzeniu, ściśle określającemu sposób postępowania, działania, czyli praxis, może zaradzić tylko wiedza, która stawia prawdę w centrum swojego zainteresowania. Bez względu na koszty i trudności. Nie ulega wątpliwości, że zarówno przewartościowanie agere kosztem esse, jak również ich separowanie, niesie ze sobą wielkie szkody dla jednego i drugiego wymiaru. Zważywszy na podstawowe, wspomniane kryteria ich wartości i znaczenia w życiu ludzkim, otwartym na wymiar doczesny i eschatologiczny, potrzebne są kompetencje, zarówno w określaniu kim człowiek jest jak i co powinien robić ${ }^{101}$. Naturalnie z uwzględnieniem wiąząacego jedno i drugie porządku, w którym człowiek został stworzony oraz odkupiony. W tym sensie teologia jako wiedza praktyczna nie stanowi dodatku do teologicznego poszukiwania i określania prawdy, ale jest owej prawdy i w tym samym znaczeniu teologii jako takiej, nieodzowną częścią!

Na koniec wróćmy jeszcze do ks. Bartnika, co może być też powrotem do o. Woronieckiego. Czy Bartnik, pragnący spotkać się po śmierci ze staroegipskimi kapłanami, spodziewał się czegoś od nich dowiedzieć, czy też chciał im coś powiedzieć? Jak się wydaje w jednym i w drugim przypadku, uznał ich za przygotowanych do tego. Podstawą bowiem głoszenia przez nich przebóstwienia ludzkiej duszy - o czym Ksiądz Profesor na pewno wiedział - była Maat, wyrażająca tryteistyczny obraz świata (zarządzania, komunikowania i działania) i przez ludzkie serce - jako wszystko przenikająca i regulująca siła - wiążąca zewnętrzny porządek z rozwiązaniami społecznymi (państwowymi) ${ }^{102}$.

\footnotetext{
101 M. Jagodziński, Antropologia komunijna, Lublin 2015, s. 45-58.

102 E. Brunner-Traut, Frühformen des Erkennens: Aspektive im alten Ägypten, Darmstadt 1992, s. 94-98.
} 
Chociażby przez występujące $\mathrm{w}$ tej koncepcji elementy (serce, wewnętrzne decyzje i zewnętrzny, obiektywny porządek), w perspektywie chrześcijaństwa, staroegipska Maat stanowi bardzo odległą, ale wprost narzucającą się intuicję potrzeby uwewnętrznienia prawa. Nie tylko po to, aby potwierdzić skuteczność i sprawiedliwośćc ${ }^{13}$ prawa w jego autonomii i heteronomii. Również dlatego, aby zewnętrzny, uznany za obowiązujący i pochodzący z Boskiego świata porządek, był też doświadczeniem wewnętrznym, potwierdzając w ten sposób jedność. Za każdym razem, kiedy porządki te przedstawiane są jako odległe, oddala się rzeczywistość przebóstwienia, czyli wydarzenia Jezusa Chrystusa i właściwego rozumienia teologii jako zupełnej wiedzy. To znaczy wystarczającej, aby doświadczyć, że jest się kochanym i aby kochać, co niekoniecznie musi oznaczać: od razu wszystko wiedzieć ${ }^{104}$.

Słowa kluczowe: teologia, wiedza, nauka, praktyka, wiara, prawda, miłość, mądrość, poznanie, wolna wola, filozofia.

\section{Bibliografia:}

1. Allen J. A., Irreligion. A Mathematician Explains Why the Arguments for God Just Don't App Up, New York 2009.

2. Andrade C. G., Boskie atrybuty w świetle nauki o Trójcy Świętej, tłum. G. Ostrowski, Poznań 2003.

3. Andrzejuk A., Franciszek Sawicki: Filozofia mitości, [w:] Metafizyka obecności. Wstęp do teorii relacji osobowych, Warszawa 2012, s. 343-358.

4. Apokalipsa Barucha Syryjska, tłum. J. Woźniak, [w:] Apokryfy Starego Testamentu, (red.) R. Rubinkiewicz, Warszawa 1999.

5. Augustyn, O Trójcy Świętej, tłum. M. Stokowska, Kraków 1996.

6. Augustyn, Państwo Boże, tłum. W. Kubicki, Kęty 1998.

7. Augustyn, Przeciw Sekundynowi, tłum. J. Sulowski, Warszawa 1999.

8. Augustyn, Solilokwia, I, 1, tłum. A. Świderkówna, [w:] tenże, Dialogi filozoficzne, Kraków 1999.

9. Babiński J., Teologia życia. Próba reinterpretacji dorobku ks. Franciszka Sawickiego, Pelplin 2013.

10. Balthasar H. U., Pisma wybrane, t. 1, Pisma filozoficzne, thum. M. Urban, D. Jankowska, Kraków 2006.

11. Balthasar H. U., Teodramatyka, 1 Prolegomena, tłum. M. Mijalska, M. Rodkiewicz, W. Szymona, Kraków 2005.

103 B. Häring, Powszechne królewskie wtadztwo Boga. Teologia moralna szczegótowa, cz. II, Poznań 1963, s. 36-45.

104 „Prawdziwa miłość ma to do siebie, iż wcale nie pragnie być do końca zrozumiana. Ona chce przede wszystkim być doznawana" A. Nossol, Przez prawdę do miłości. Ewangeliczna wierność słowu Bożemu, Opole 1994, s. 22. 
12. Balthasar H. U., Teodramatyka, 2 Osoba dramatu, cz. I, Człowiek w Bogu, tłum. W. Szymona, Kraków 2006.

13. Balthasar H. U., Teologika, 1 Prawda świata, tłum. J. Zychowicz, Kraków 2004.

14. Balthasar H. U., Teologika, 2 Prawda Boga, tłum. J. Zychowicz, Kraków 2004.

15. Balthasar H. U., Teologika, 3 Duch Prawdy, tłum. J. Zychowicz, Kraków 2005.

16. Barrow J., Theories of Everything: The Qwest for Ultimate Explanations, Oxford University Press 1991.

17. Bator W., Myśl starożytnego Egiptu, Kraków 1993.

18. Bendykt XVI, Deus caritas est, Watykan 2005.

19. Benedykt XVI, Fundamentem prawdziwej kultury jest poszukiwanie Boga, (Paryż 12 września 2008), „L'Osservatore Romano” (wyd. polskie), 10-11 (2008), s. 12-16.

20. Bergson H., Dwa źródła moralności i religii, tłum. P. Kostyło, Kraków 1993.

21. Bokwa I., Teologia w warunkach nowoczesności i ponowoczesności, Sandomierz 2010.

22. Booth R. P., Jesus and the Laws of Purity: Tradition History and Legal History in Mark 7, Trowbridge 1986.

23. Brague R., La Sagesse du monde. Histoire de l'expérience humaine de l'univers, Paryż 1999.

24. Brague R., Prawo Boga. Filozoficzna historia przymierza, tłum. M. Wodzyńska, A. Kocot, Warszawa 2014.

25. Brunner-Traut E., Frühformen des Erkennens: Aspektive im alten Ägypten, Darmstadt 1992.

26. Brunschvicg L., Rozwój świadomości w filozofii zachodniej (fragmenty), tłum. T. Śliwiński, Kraków 2005.

27. Być dla, czyli myśleć sercem. Z ks. biskupem A. Nossolem rozmawia ks. J. Szymik, Katowice 1999.

28. Być silnym, żeby być łagodnym, Z s. Małgorzatą Chmielewska rozmawia Ewa Kiedio, „Więź” LVI (2013) nr 3 [653], s. 18-25.

29. Chenu M. D., Wybór pism, tłum. L. Rutkowska, W. Sukiennicka, Z. Włodkowa, Warszawa 1971.

30. Chrostowski W., Między Synagoga a Kościołem. Dzieje św. Pawła, Kraków - Ząbki 2015.

31. Czaja A., Jedna osoba w wielu osobach. Pneumatologiczna eklezjologia Heriberta Mühlena, Opole 1997.

32. Daniélou J., Trójca Święta i tajemnica egzystencji. Znaki światyni czyli obecności Boga, tłum. M. Tarnowska, Kraków 1994.

33. Davies P., Ostatnie trzy minuty. O ostatecznym losie wszechświata, Warszawa 1995.

34. Despres V., Początki monastycyzmu, t. 2, tłum. J. Dembska, Kraków 1999.

35. Falk Z. W., Law and Religion. The Jewish Experience, Jerozolima 1981.

36. Ferdek B., Światło wiary w obliczu światła rozumu, [w:] Problem kulturowo-religijnej reinterpretacji współczesnej Europy, (red.) J. Moskałyk, Poznań 2019, s. 137-148.

37. Fransen P., Das neue Sein des Menschen in Christus, [w:] Mysterium Salutis, (red.) J. Fejner, M. Löhrer, t. 4, Einsiedeln 1973, s. 921-983.

38. Frye N., The Great Code, Routledge and Kegan Paul 1982. 
39. Greshake G., Wierzę w Boga Trójjedynego. Klucz do zrozumienia Trójcy Świętej, tłum. W. Szymona, Kraków 2001.

40. Halik T., Co nie jest chwiejne. Labiryntem świata z wiara $i$ watpliwościami, tłum. J. Zychowicz, Kraków 2004.

41. Hawking S., A brief History of Time, Bantam Press 1988.

42. Häring B., Powszechne królewskie władztwo Boga. Teologia moralna szczegótowa, cz. II, Poznań 1963.

43. Häring B., Sita i słabość religii. Socjologia religii jako wyzwanie, tłum. J. Klenowski, Poznań 1966.

44. Häring B., Świętość a dobro. Wzajemny stosunek religii i moralności, Poznań 1963.

45. Häring B., Zasadnicza postać chrześcijańskiego życia. Teologia moralna ogólna, t. I, tłum. J. Klenowski, Poznań 1962.

46. Häring B., Z mitości ku mitości. Teologia moralna szczegótowa, cz. I, tłum. J. Klenowski, Poznań 1963.

47. Heller M., Nowa fizyka i nowa teologia, Tarnów 1992.

48. Heller M., Wszechświat i Stowo, Kraków 1994.

49. Heller M., Nowa fizyka i nowa teologia, Tarnów 1992.

50. Heller M., Liana Z., Mączka J., Skoczny W., Nauki przyrodnicze a teologia: konflikt $i$ wspótistnienie, Tarnów 2001.

51. Heller M., Życiński J., Drogi myślacych, Kraków 1983.

52. Historia Teologii, t. I, Epoka patrystyczna, (red.) A. di Berardino, B. Studer, Kraków 2003.

53. Historia Teologii, t. II, Epoka średniowieczna, tłum. W. Szymona, (red.) G. D'Onofrio, Kraków 2010.

54. Historia Teologii, t. III, Epoka Odrodzenia, tłum. W. Szymona, (red.) G. D'Onofrio, Kraków 2008.

55. Historia Teologii, t. IV, Epoka nowożytna, tłum. W. Szymona, (red.) G. Angelini, G. Colombo, M. Vergottini, Kraków 2008.

56. Höffe O., Immanuel Kant, tłum. A. M. Kaniowski, Warszawa 2003.

57. Hume D., Eseje z dziedziny moralności, polityki i literatury, tłum. Ł. Pawłowski, Warszawa 2013.

58. Hutten E. H., Idee fizyki, Warszawa 1976.

59. Izbicki T. M., Protector of the Faith. Cardinal Johannes de Turrecremata and the Defense of Institutional Church, Washington 1981.

60. Jagodziński M., Antropologia komunijna, Lublin 2015.

61. Jagodziński M., Węztowe zagadnienia chrystologii komunijnej, Radom 2013.

62. Kaniowski A. M., Filozofia praktyczna Immanuela Kanta - jej siła i stabości, „Diametros" 2 (2004), s. 114-126.

63. Kasper W., Rzeczywistość wiary, tłum. J. Piesiewicz, Warszawa 1979.

64. Kawalec P., Wiedza, [w:] Encyklopedia katolicka, t. XX, (red. nacz.) E. Gigilewicz, Lublin 2014, kol. 485-487.

65. Kazen T., Jesus, Scripture and Paradosis: Response to Friedrich Avemarie, [w:] The New Testament and Rabbinic Literature, (red.) R. Biringer, F. G. Martinez, D. Pllefeyt, P. J. Tomson, Boston - Leiden 2010. 
66. Kiejkowski P., Trzy stowa papieża Benedykta XVI dla Europy. W trosce o integralny humanizm, [w:] Problem kulturowo-religijnej reinterpretacji wspótczesnej Europy, (red.) J. Moskałyk, Poznań 2019, s. 89-106.

67. Kijas Z. I., Początek świata i człowieka, Kraków 2004.

68. Koneczny F., Cywilizacja Bizantyńska, Londyn 1973.

69. Kozak M., Kościót jako communio wedtug Gerarda Philipsa, Lublin 2003.

70. Ksenofont z Efezu, Pisma sokratyczne, tłum. L. Joachimowicz, Warszawa 1967.

71. Kuligowski R., Jak żyć wiara?, [w:] Perspektywy wiary, (red.) M. Jagodziński, Radom 2015, s. 127-141.

72. Kumor B., Historia Kościoła. Czasy nowożytne. Rozłam w chrześcijaństwie zachodnim, t. 5, Lublin 1984.

73. Langkammer H., Teologia biblijna Starego i Nowego Testamentu, Legnica 2007.

74. Laurentin R., Nowe wymiary mitości, tłum. M. Bocheńska, Warszawa 1977.

75. Lindberg C., Historia mitości w zachodnim chrześcijaństwie, tłum. M. Höffner, Kraków 2012.

76. Lubański M., Filozoficzne zagadnienia teorii informacji, Warszawa 1976.

77. Marks K., Tezy o Feuerbachu, [w:] tenże, Dzieła, t. III, Warszawa 1961.

78. Merklein H., Jesu Botschaft von der Gottesherrschaft, Stuttgart 1983.

79. Morales J., Wprowadzenie do teologii, tłum. P. Rak, Kraków 2006.

80. Müller G. L., Raport o stanie nadziei. Rozmowa z Carlosem Granadosem, thum. K. Jasiński, Warszawa 2018.

81. National Academy of Sciences, Teaching About Evolution and the Nature of Science, Washington 1998.

82. Nitecki P., Quod est veritas? Spotkanie z Jezusem w pretorium Pitata, „Życie i Myśl” 25 (2009), s. 71-80.

83. Newman J. H., O rozwoju doktryny chrześcijańskiej, tłum. J. Zielińska, Warszawa 2000 .

84. Nietzsche F., Niewczesne rozważania, tłum. L. Staff, Warszawa 1912.

85. Nietzsche F., Poza dobrem i ztem, tłum. S. Wyrzykowski, Warszawa 1907.

86. Nossol A., Przez prawdę do mitości. Ewangeliczna wierność słowu Bożemu, Opole 1994.

87. Nossol A., Teologia blizsza życiu. Wplyw teologii na egzystencję chrześcijańska, Paris 1993.

88. Oakley F., Christian Theology and the Newtonian Science. The Rise of the Concept of the Laws of Nature, „Church History” 30 (1961), s. 433-457.

89. Osuna F. D., Tercer Abecedario Espirytual, Madrid 1972.

90. Owidiusz, Metamorfozy, tłum. A. Kamieńska, S. Stabryła, Wrocław 1995.

91. Paciorek A., Człowiek bez Chrystusa w soteriologii Listu św. Pawła do Rzymian, Tarnów 1995.

92. Paszyński J., Eudajmonizm, t. 3, Lublin 2002.

93. Popper K. R., Objective Knowledge - An Evolutionary Approach, Oxford, At the Clarendon Press, 1975.

94. Przygoda W., Uwierzyć mitości, by stać się świadkiem mitości, [w:] Perspektywy wiary, (red.) M. Jagodziński, Radom 2015, s. 69-91.

95. Pseudo-Platon, Zimorodek i inne dialogi, tłum. L. Regner, Warszawa 1985. 
96. Rahner K., Pisma wybrane, t. 1, tłum. G. Bubel, Kraków 2005.

97. Rahner K., Podstawowy wyktad wiary. Wprowadzenie do pojęcia chrześcijaństwa, tłum. T. Mieszkowski, Warszawa 1987.

98. Rahner K., Praxis des Glaubens. Geistliches Lesebuch, Freiburg - Basel - Wien 1984.

99. Ratzinger J., Europa - dziedzictwo zobowiazujace chrześcijan, tłum. L. Balter, [w:] Kościót - ekumenizm - polityka, „Communio” - kolekcja 5, Poznań 1990.

100. Ratzinger J., Jezus z Nazaretu, cz. I, tłum. W. Szymona, Kraków 2007.

101. Ratzinger J., Lud i Dom Boży w nauce św. Augustyna o Kościele. Rozprawa doktorska oraz inne opracowania nauki Augustyna i teologii ojców Kościoła, „Opera Omnia”, t. I, tłum. W. Szymona, (red.) K. Góźdź, M. Górecka, Lublin 2014.

102. Ratzinger J., Prawda - wartości - władza. Kiedy spoleczeństwo można uznać za pluralistyczne, tłum. G. Sowiński, Kraków 1999.

103. Ratzinger J., Rozumienie objawienia i teologia historii wedlug Bonawentury. Rozprawa habilitacyjna i studia nad Bonawentura, ,Opera Omnia”, t. II, tłum. J. Merecki, (red.) K. Góźdź, M. Górecka, Lublin 2014.

104. Ratzinger J., Wiara w Piśmie $i$ Tradycji. Teologiczna nauka o zasadach, tłum. J. Merecki, „Opera Omnia”, t. IX/1, (red.) K. Góźdź, M. Górecka, Lublin 2018.

105. Ratzinger J., Wiara w Piśmie $i$ Tradycji. Teologiczna nauka o zasadach, tłum. J. Merecki, „Opera Omnia”, t. IX/2, (red.) K. Góźdź, M. Górecka, Lublin 2018.

106. Ratzinger J., W rozmowie z czasem, „Opera Omnia”, t. XIII/2, (red.) K. Góźdź, M. Górecka, Lublin 2017.

107. Ratzinger J., Zmartwychwstanie $i$ życie wieczne. Studia o eschatologii $i$ teologii nadziei, tłum. J. Kobienia, „Opera Omnia”, t. X, (red.) K. Góźdź, M. Górecka, Lublin 2014.

108. Rękopisy znad Morza Martwego. Qumran, tłum. P. Muchowski, Kraków 2000.

109. Ricoeur P., The Rule of Metaphor, London 1978.

110. Rosenzweig F., Gwiazda Zbawienia, tłum. T. Gadacz, Kraków 1998.

111. Rosik M., Kościół a synagoga (30-313 po Chr.) na rozdrożu, Wrocław 2016.

112. Roszkowski W., Roztrzaskane lustro. Upadek cywilizacji zachodniej, Kraków 2019.

113. Sacharow A. D., Mein Land und die Welt, Wien 1972.

114. Sartre J.-P., L 'etre et le ne 'ant, Paris 1979.

115. Sartre J.-P., Mdłości, tłum. J. Trznadel, Warszawa 1974.

116. Sartre J.-P., Le`vy B., Czas nadziei, tłum. H. Puszko, Warszawa 1996.

117. Sawicki F., Die Gottesbeweise, Paderborn 1926.

118. Sawicki F., Die Wahrheit des Christentums, Paderborn 1918.

119. Sawicki F., Filozofia milości, Poznań 1937.

120. Sawicki F., Filozofia życia, Poznań 1936.

121. Sawicki F., Osobowość chrześcijańska, Kraków 1947.

122. Sawicki F., Św. Augustyn pierwszym czlowiekiem nowożytnym, [w:] Święty Augustyn, (red.) S. Bross, Poznań 1930, s. 222-237.

123. Sawicki F., Życie ludzkie, Poznań 1936.

124. Scheffczyk L., Die Theologie und die Wissenschaften, Aschaffenburg 1989.

125. Schopenhauer A., O wolności ludzkiej woli, tłum. A. Stögbauer, Warszawa 1991. 
126. Solignac A., Massein P., Gribomont J. i in., Monastycyzm. Historia i duchowość, tłum. D. Stanicka-Apostoł, Kraków 2002.

127. Szymik J., O teologii dzisiaj. Zadania, piękno, przyszłość, Pelplin 2006.

128. Štrukelj A., Teologia i świętość, tłum. M. Jagodziński, Lublin 2010.

129. Taubes J., Die politische Theologie des Paulus, Monachium 1993.

130. Trame R. H., Rodrigo Sáncheza de Arévalo. Spanish dyplomat and champion of Papacy, Washington 1958.

131. Urban M., Hans Urs von Balthasar - otwarty rozum, [w:] Hans Urs von Balthasar, Pisma wybrane, t. 1, Pisma filozoficzne, tłum. M. Urban, D. Jankowska, Kraków 2006, s. 5-17.

132. Vernant J.-P., Źródła myśli greckiej, tłum. J. Szacki, Gdańsk 1996.

133. Waldenfels H., O Bogu, Jezusie Chrystusie i Kościele - dzisiaj. Teologia fundamentalna w kontekście czasów obecnych, tłum. A. Paciorek, Katowice 1993.

134. Walicki A., Marksizm i skok do królestwa wolności. Dzieje komunistycznej utopii, Warszawa 1996.

135. Węcławski T., W teologii chodzi o ciebie. Przewodnik po źródłach i skutkach teologicznej wyobraźni, Kraków 1995.

136. Wojtkun J., Lumen fidei $i$ Veritatis splendor - światło wiary w blasku prawdy moralnej, [w:] Perspektywy wiary, (red.) M. Jagodziński, Radom 2015, 143-163.

137. Wróbel M. S., Antyjudaizm a Ewangelia wedtug św. Jana. Nowe spojrzenie na relację czwartej Ewangelii do Judaizmu, Lublin 2005. 